wal, forest entomologist, Forest Research Institute, Dehra Dun. '1 reasurer: Dr. B. S. Chauhan, Zoo logical Survey of India, Calcutta. Editor : Dr. B. N. Chopra, fisheries development adviser, Government of India, New Delhi. Members of Council: Dr. H. S. Pruthi, plant protection adviser to the Govern ment of India, Ministry of Agriculture, New Delhi; Dr. N. K. Panikkar, chief research officer, Central Marine Fisheries Research Station, Mandapam; Prof. A. B. Misra, professor of zoology, Banaras Hindu University; Prof. H. R. Mehra, professor of zoology, University of Allahabad; Prof. R. V. Seshaiya, professor of zoology, Annamalai Univer sity; Prof. Bhaskaran Nair, professor of zoology, University College, Trivandrum.

\section{Information Bulletin of the U.S. National Academy of Sciences and National Research Council}

THE United States National Academy of Sciences and the National Research Council are now issuing free of charge to all organizations and individuals directly associated with the Academy or the Research Council a new information bulletin, News Report, the first number of which (1, No. 1, January-February ; pp. 20) illustrates the present concept of the scope of the new publication. It includes an article on the scientific man-power situation in the United States, by M. H. Trytten, director of the Office of Scientific Personnel, another by $\mathrm{O}$. M. Ray describing the functions of the Committee on Growth, created in 1945 to advise the American Cancer Society on the support of scientific research in problems of malignant and normal growth, and another by R. W. Crum on the work of the Highway Research Board. Features such as "Science News", "Seientific Personnel" and "International Relations" record activities in different branches of science, openings such as Fulbright fellowships, trends in advanced training, and the activities of the international scientific unions. Besides the calendar of international congresses included in the last-named feature, there are a further schedule of meetings during the year of affiliated societies and a calendar of meetings of the Academy and the Research Council, with a list of their new publications. The annual subscription for those not receiving News Report automatically is 2 dollars, to be sent to the editorial office at 2101 Constitution Avenue, Washington 25, D.C.

\section{University of London: Appointments}

THE following appointments have been made in the University of London: Dr. D. R. Crofts, to the University readership in zoology tenable at King's College of Household and Social Science, from October 1; Dr. Werner Ehrenberg, to the University readership in physics tenable at Birkbeck College, from October 1 .

\section{"New Inhibitors of the First Stage of the Blood- clotting Process"}

Dr. E. Hecht, whose communication under this title appeared in Nature of February 17, p. 279 points out that it does not quite conform to the reprints which have been prepared: thus, for "Sphingosine has the same solubility properties as Tocantins's 'anticephalin's but differs from the latter by being thermostable" read (as in reprint) : "Sphingosine has the same solubility properties as Tocantins's 'anticephalin's, but the latter has been shown by partition chromatography to be a mixture of our non-protein activator, sphingomyelin and sphingosin". The following reference should also be added : Tocantins, L. M., and Carroll, R. T., "Blood Clotting and Allied Problems", edited by J. E. Flynn, New York (1949).

\section{Announcements}

Dr. Ilimo HeI A, at present assistant professor of geophysics in the University of Helsinki and lecturer in meteorology in the Institute of Technology, University of Finland, has been appointed assistant professor of oceanography in the University of Miami Marine Laboratory. Dr. Hela will carry out research into problems connected with the Florida Current and other water-movements in the Gulf of Mexico and Caribbean Sea.

The Textile Institute, at 16 St. Mary's Parsonage, Manchester, 3, is prepared to assist research conducted on cotton spinning, doubling and twisting, and is offering grants from the Frank Wright Memorial Fund to persons of British nationality. Further details can be obtained from the general secretary of the Institute.

The Medical Research Council is offering a Kathleen Schlesinger fellowship for research on the origin and nature of cysts of the brain whether arising from tumours or not or for studies of other conditions of the central nervous system as the Council may permit. The fellowship is ordinarily tenable at the National Hospital for Diseases of the Nervous System, Queen Square, London, W.C.1, and is worth $£ 700-1,000$ a year for one year initially and renewable up to three years. Application forms, obtainable from the Secretary, Medical Research Council, 38 Old Queen Street, London, S.W.1, must be completed by May 31.

THE Development Commission announces that it is offering a few grants to British postgraduate honours students for training in research problems in marine or freshwater science, which is designed primarily to fit them for employment either in the fishery research services of the Ministry of Agriculture and Fisheries and the Scottish Home Department or in a marine or freshwater biological research institute. The grants are worth $£ 220-300$ a year with extra university fees paid, together with a marriage allowance, and are tenable initially for one year but renewable up to a maximum of three years. Application forms, to be returned by June 1, can be obtained from the Secretary, Development Commission, $6 a$ Dean's Yard, Westminster, London, S.W.1.

THE Department of Inorganic and Physical Chemistry of the University of Leeds is arranging a postgraduate summer school on "Optical Crystallographic Methods", to be held in Leeds during September 3-14, which will be similar to those organized at University College, Swansea, in 1946 and 1947. The course will provide basic training in the theory and use of the polarizing microscope in the study of crystals and other birefringent materials, and in the applications of the instrument in other branches of science and technology. Fees for the course are 15 guineas for tuition and 9 guineas for accommodation. Enrolment forms, obtainable from Miss M. Spink, Assistant to the Director of Extra-Mural Studies, University, Leeds, 2, must be completed by May 11 .

Erratum. In the communication "Antitumourigenic Action of Steroids . . ." by Prof. A. Lipschutz. et al. in Nature, February 10, on p. 236, col. 1, par. 3 , line 2, for "4 $4 \mathrm{gm}$." read "42 $\mu \mathrm{gm}$.". 